\title{
Estetika Batik Tulis Motif “Bintang Laut” Pekalongan, Jawa Tengah (Kajian Estetika)
}

\author{
Fajrul Falah
}

Fakultas Ilmu Budaya, Universitas Diponegoro

fajrulfalah7@gmail.com

\begin{abstract}
Aesthetic research on Pekalongan batik is rare and limited. Several studies related to Pekalongan batik are studied from the economic aspect (production, distribution, and consumption) and health (disease). This study aims to reveal the aesthetics of motif batik "bintang laut" Pekalongan Central Java. The research approach used is aesthetics that include, unity, dominance and balance. This research is a literature study. The method used is descriptive analytics. The source of this research data is batik motif in Pekalongan. The selected and taken sample is one of the batik motifs in Pekalongan, "bintang laut". The results show batik motif "bintang laut" has a beauty and contains three esthetic elements. Miniature marine fauna and balanced color combinations and the size of different "bintang laut", adding to the aesthetic impression and originality of batik that the way of making it still using the hand (manual).
\end{abstract}

Keywords: Batik, estetika, color, balanced, Pekalongan.

\section{Intisari}

Penelitian estetika terhadap batik Pekalongan jarang dilakukan dan terbatas. Beberapa penelitian terkait batik Pekalongan dikaji dari aspek ekonomi (produksi, distribusi, dan konsumsi) dan kesehatan (penyakit). Penelitian ini bertujuan mengungkapkan estetika batik tulis motif "bintang laut" Pekalongan Jawa Tengah. Pendekatan penelitian yang digunakan adalah estetika yang meliputi, keutuhan (unity), penonjolan (dominance) dan balance (keseimbangan). Penelitian ini merupakan studi kepustakaan. Metode yang digunakan adalah deskriptif analitik. Sumber data penelitan ini adalah motif batik di Pekalongan. Sampel yang dipilih dan diambil adalah salah satu motif batik di Pekalongan, yaitu "bintang laut". Sampel diambil dari pustaka kemudian diidentifikasi dan analisis dengan pendekatan esetetika. Hasil penelitian menunjukkan batik motif "bintang laut" memiliki keindahan dan mengandung tiga unsur estetik. Miniatur fauna laut dan kombinasi warna yang seimbang dan ukuran "bintang laut" yang berbeda-beda, menambah kesan estetis dan orisinalitas batik tulis yang cara pembuatannya masih menggunakan tangan (manual).

Kata kunci: Batik tulis, estetika, warna, seimbang, Pekalongan. 


\section{Pendahuluan}

Batik merupakan karya seni yang dimiliki Indonesia. Karya seni batik bahkan oleh UNESCO diakui sebagai warisan kemanusiaan dan budaya Indonesia. Sebagai produk (ke) budaya (an), batik di Indonesia tersebar dan cukup terkenal di beberapa daerah di antaranya Pekalongan, Solo, Yogyakarta, Lasem, Lampung, Toraja, Makassar, dan Kalimantan. Tiap-tiap daerah tersebut, memiliki produk batik dengan motif masing-masing. Salah satu daerah yang cukup terkenal dan mendapatkan julukan sebagai kota batik adalah Pekalongan, Jawa Tengah. Sebagai ikon kota batik, di Pekalongan terdapat relatif banyak motif batik (jlamprang, semen, lion) yang beredar di pasaran, baik domestik maupun mancanegara (ekspor). Salah satu motif batik yang terdapat di kota santri tersebut adalah batik motif "bintang laut", yang merupakan batik tulis.

Batik merupakan (karya) seni masyarakat Indonesia yang dibuat dengan umumnya menggunakan canting dan bahan lilin (malam). Istilah batik diambil dari kata ngembat titik. Ngembat memiliki arti mengambil (baca: membuat) dan tik berarti titik. Ada beberapa jenis batik di Pekalongan. Selain batik tulis, di Pekalongan terdapat batik printing dan cap. Kategori batik tersebut didasarkan pada proses pembuatanya. Batik tulis dibuat dengan cara pelekatan canting tulis di atas kain (mori) secara manual (tradisional). Proses pembuatannya relatif lebih lama, susah, dan harganya pun lebih mahal dibandingkan batik printing dan cap. Karena harganya mahal, jenis batik tulis ini tidak mudah didapatkan di berbagai tempat (pasaran), batik tulis bisa didapatkan di toko-toko batik yang relatif besar. Adapun batik cap dan printing dibuat dengan cara canting cap yang terbuat dari tembaga yang sudah dibentuk (setting) motif-motif pilihan dicelupkan ke cairan malam kemudian dicapkan ke kain. Proses produksi batik cap printing lebih cepat (berkisar 5 menit) untuk sekali pewarnaan (lihat Sudantoko, 2010: 105-107).

Dua kategori batik tersebut di atas memiliki "kekurangan" dan keunggulan masing-masing. Meskipun demikian, dari sisi keindahan, batik tulis masih menjadi pilihan utama (prioritas) dibandingkan batik cap dan printing. Proses manual atau tradisional yang masih mengedepankan kelihaian tangan pembatik 
dan kualitas kain serta aneka ragam motif masih menjadi unggulan dan menambah kesan indah batik tulis. Keindahan motif batik tulis yang tercipta dari perpaduan warna ini dapat diklasifikasikan sebagai keindahan visual dan masuk ranah pendekatan estetika (keindahan).

Ada tiga (3) unsur estetik yang mendasar dalam struktur karya seni. Ketiga unsur itu menurut Djelantik (2004), yakni unity (keutuhan), dominance (penonjolan), dan balance (keseimbangan). Pertama, unity (keutuhan) karya disebut indah manakala adanya sifat yang utuh, tidak kurang dan lebih, tidak cacat. Antarbagian terdapat relevansi dan memiliki makna. Tia-tiap bagian saling mengisi dan menujukkan kekompakkan. Kedua, dominance (penonjolan). Dominance karya seni dilihat dari dominasi aspek tertentu yang dianggap paling penting dibandingkan aspek yang lain. Dalam kontek karya seni, penonjolan ditandai dengan kontras atau ciri khusus (karakter). Ketiga, balance (keseimbangan). Karya seni yang balance mudah tercapai dengan simetri, meskipun keseimbangan juga bisa dicapai tanpa simetri (asimetri). Balance warna dalam susunan kombinasi, bisa proporsional, masing-masing bidang sama (simetri) atau justru berbeda (asimetri).

Ketiga unsur keindahan karya seni di atas, apakah diindikasikan terdapat dalam motif batik tulis "bintang laut" Pekalongan? Keindahan batik tersebut menarik dikaji dengan pendekatan estetika Djelantik. Sepanjang yang penulis ketahui dari jelajah internet, e-book, jurnal (terindeks doaj.org) belum ditemukan penelitian terkait estetika motif batik "bintang laut" Pekalongan.

Beberapa penelitian yang terkait batik Pekalongan dan estetika batik dari perspektif lain adalah (1) Salma dan Eska (2012), mengkaji estetika batik khas Sleman "Semarak Salak". Fokus kajian dalam penelitian ini adalah nilai-nilai keindahan universal batik Sleman. Hasil penelitan menunjukkan batik Sleman "Semarak Salak" memiliki makna filosofis, kesesuaian ciri khas Sleman, keindahan komposisi warna. Rizza (2013), mengkaji pembuangan limbah cair batik di Pekalongan. Fokus penelitian ini hubungan kondisi fisik sumur gali dengan kadar nitrit sumur gali di Podosugih, Pekalongan. Hasil penelitian 
menunjukkan kandungan nitrit sumur gali di Podosugih melebihi batas maksimal $(34,78 \%)$.

Pramitasari (2014), mengkaji batik Kota Pekalongan dari segi register. (pemakaian bahasa pelaku industri). Fokus penelitian ini adalah pemakaian bahasa perilaku indsutri batik Pekalongan. Hasil penelitian menunjukkan terdapat dua bentuk register, yakni satuan lingual bahasa (kata tunggal dan kompleks) dan jenis kata. Latif, dkk (2016), mengkaji batik Pekalongan dari aspek profil potensi penyakit. Fokus penelitian ini adalah identifikasi penyakit (gangguan kesehatan) akibat pembatikan. Hasil penelitian menunjukkan penyakit para pekerja batik di antaranya penurunan fungsi penglihatan $(33.8 \%$ ) dan gangguan kapasitas paru $(67.5 \%)$.

Penelitan-penelitian tersebut di atas mengkaji batik Pekalongan dari perspektif lain, bukan estetika. Jika selama ini sebagian besar penelitian batik Pekalongan difokuskan pada sektor ekonomi (produksi, distribusi, dan konsumsi) dan kesehatan (dampak penyakit). Penelitian ini akan mengungkap persoalan bagaimankah estetika motif batik tulis "bintang laut" Pekalongan. Apakah warnawarna yang membentuk motif tersebut dibuat sekadar meniru protret alam (ciptaan) ataukah justru memililiki keindahan dari kombinasi warna? Penelitian ini dikaji dan masuk ranah estetika.

\section{Metode Penelitian}

Penelitian ini merupakan penelitian studi kepustakaan. Metode yang digunakan adalah deskriptif analitik. Sumber data penelitan ini adalah motif batik di Pekalongan. Sampel yang dipilih dan diambil adalah salah satu motif batik di Pekalongan, yaitu motif batik tulis "bintang laut". Sampel motif batik ini yang diambil dari pustaka ini, lalu diidentifikasi melalui warna-warna yang membentuk motif batik "bintang laut". Warna dan motif batik tersebut kemudian dianalisis dengan pendekatan estetika. Pendekatan estetika digunakan untuk mengungkap keindahan motif batik tulis "bintang laut" Pekalongan. 


\section{Hasil Penelitian}

\section{Estetika Motif Batik “Bintang Laut” Pekalongan}

Berikut ini analisis terhadap gambar 1 dari segi estetika yang meliputi unity (keutuhan), balance (penonjolan), dan balance (keseimbangan).

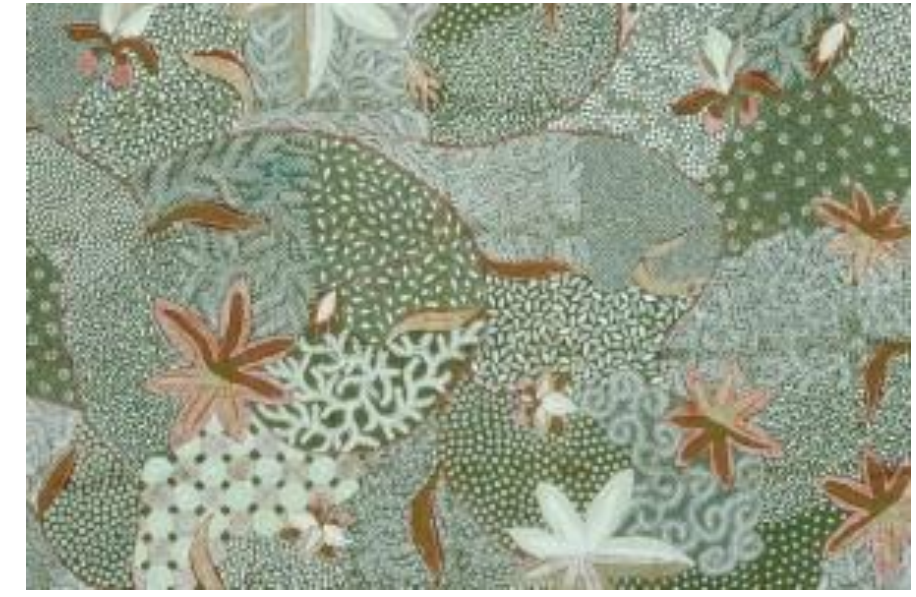

Gambar 1

(Motif batik tulis "bintang laut" Pekalongan)

\section{Pertama, Unity (Keutuhan)}

Keutuhan batik tulis "bintang laut" pada gambar 1, adanya kombinasi warna yang membentuk motif. Terdapat warna hijau (muda dan tua), cokelat (tua dan muda), dan putih. Kombinasi warna hijau dan cokelat, ditambah sedikit warna putih tidak bisa dipisahkan dan saling melengkapi sehingga membentuk ragam hias yang indah. Kombinasi warna tersebut tidak terlihat dan terkesan mencolok, sehingga menentukan persepsi manusia yang ditimbul dari penglihatan. Jika warna hijau tersebut diganti dengan warna yang lebih terang dan mencolok, misalkan hitam atau merah, tentu akan menimbulkan persepsi yang berbeda bagi orang yang melihat.

Keutuhan warna gambar 1, jika dilihat secara seksama, juga terdapat pada motif bintang laut. Warna yang dihasilkan untuk membentuk fauna laut tersebut adalah kombinasi warna cokelat tua dan muda. Meskipun terdapat pula bintang laut dengan warna hijau keputihan, kombinasi dan warna tersebut merepresentasikan bentuk asli fauna bintang laut yang habitat utamanya di dasar laut. Kesamaan motif dan bentuk asli inilah menambah nilai estetik motif batik 
tersebut. Jika warna bintang laut dibuat dengan warna kontras seperti merah menyala (warna primer) atau kuning terang, tentu memberi kesan kurang indah. Hal ini karena, selain warna utama keseluruhan motif batik tersebut hijau (warna sekunder) yang tidak akan matching (cocok) dikombinasikan dengan warna-warna kontras, juga terjadi ketidaksesuain warna motif batik bintang laut dengan warna asli fauna tersebut. Oleh karena itu, pilihan (gabungan) warna yang tepat, baik secara tekstur maupun replika, member kesan dan perspektif estetik bagi yang melihat.

\section{Kedua, Dominance (Penonjolan)}
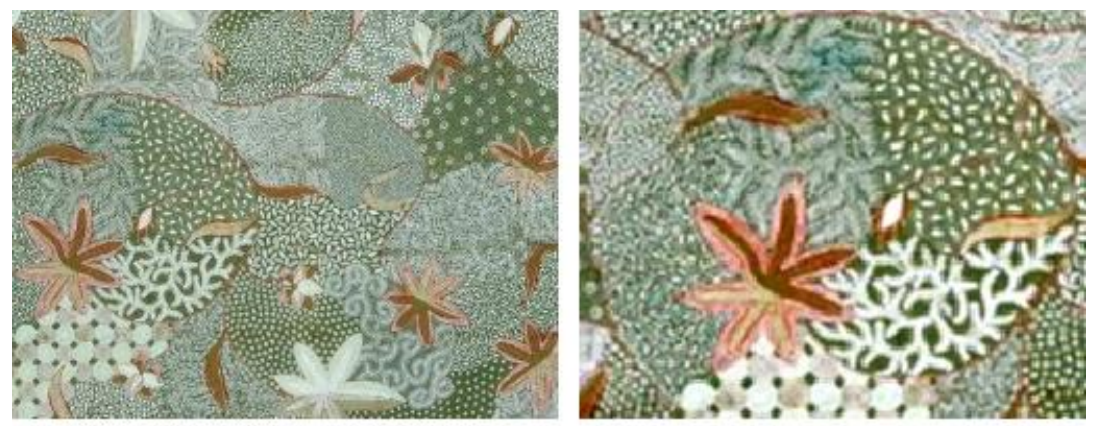

Gambar 2

(Penonjolan motif bintang laut)

Dominance atau penonjolan dalam sebuah karya seni, dalam hal ini batik tulis Pekalongan bisa membuat ciri yang khas pada pada karya seni tersebut (karakter). Ciri yang khas atau menonjol dalam batik tulis pada gambar 2 adalah hiasan bintang laut. Terdapat lima bintang laut dalam gambar tersebut dengan kombinasi warna yang berbeda. Ada bintang laut kombinasi warna cokelat tua dan muda dan bintang laut berwarna hijau muda penuh. Selain ragam hias bintang laut yang menjadi penonjolan adalah warna dasar kehijauan. Warna dasar kain batik tulis tersebut adalah hijau muda. Warna-warna seperti hijau muda, putih, cokelat tua dan muda adalah kombinasi warna tambahan dari warna dasar hijau. Jadi, nilai keindahan dari segi penonjolan batik tulis tersebut adalah hiasan bintang laut dengan variasi warnanya (khas). Penonjolan ditandai dengan warna cokelat bintang laut yang lebih terkesan soft dan nyaman dipandang. 


\section{Ketiga, Balance (Keseimbangan)}

Balance atau keseimbangan dalam motif batik tulis motif "bintang laut" dicapai dengan tanpa simetri (asimetri). Terdapat dominasi warna hijau (muda) dibandingkan warna lain seperti cokelat (tua dan muda). Demikian juga misalnya dibandingan dengan warna utama motif "bintang laut", warna hijau mendapatkan porsi dan ruang lebih luas. Selain itu, titik-titik yang menjadi ciri khas keindahan dan keunikan batik tulis Pekalongan adalah tidak simetri. Jika diperhatikan lebih cermat, tiap-tiap titik pada gambar 1 dan 2 memiliki ukuran yang berbeda dengan titik lain (asimetri). Hal ini indah dan unik karena titik-titik yang ada dalam batik tulis tersebut dibuat dengan tangan (manual atau tradisional), sehinggga potensi ketidaksamaan dan ketidakrapian ukuran dan warna relatif besar (asimetri). Asimetri warna ini menambah keindahan batik tersebut karena selain proses pembuatannya relatif sulit jika dibandingkan jenis batik lain seperti cap dan printing, juga menambah kesan orisinalitas batik tersebut.

\section{Indikator Estetika Tambahan}

Indikator-indikator estetika yang lain pada batik tulis adalah ragam hias tumbuhtumbuhan (fauna laut), komposisi warna lebih kaya, dan potongan ragam hias yang unik (tidak sama).

\section{Ragam Hias Fauna Laut (Tumbuhan)}

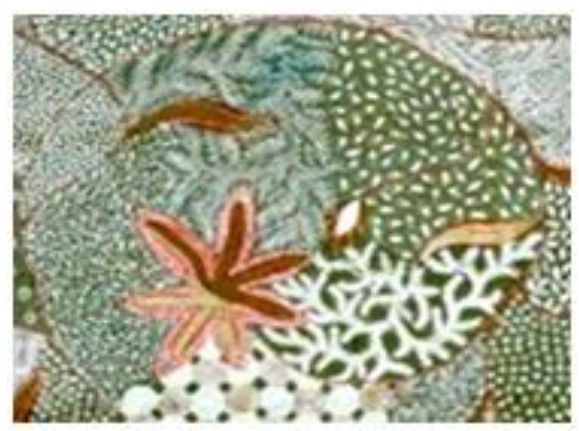

Gambar 3

(Ragam hias fauna laut)

Pada gambar 3 tersebut lebih menyorot (fokus) motif bintang (fauna) laut. Motif

"khusus" batik ini menjadi indah dan salah satu motif yang membedakan batik Pekalongan dengan batik daerah lain seperti Solo, Yogyakarta, apalagi 
Kalimantan dan Sulawesi. Selain itu, pada motif batik tulis tersebut terdapat tumbuhan-tumbuhan laut berwarna hijau muda karang dan rumput laut dengan kombinasi warna beragam dan tidak saling menutupi. Miniatur fauna laut tersebut mengkonfirmasi keindahan batik tulis motif "bintang laut" Pekalongan.

\section{Komposisi Warna Lebih Kaya (Kompleks)}

Jika dicermati dan diperhatikan lebih mendalam, maka akan ditemukan bahwa batik tulis pada gambar 3 memiliki komposisi warna yang kompleks. Komposisi warna yang kaya dan kompleks batik tulis berbeda dengan batik cap dan printing. Lingkaran kecil pada gambar 3 tersebut terdapat beberapa kombinasi warna seperti warna putih, cokelat muda dan tua, hijau muda dan tua. Kombinasi warna yang kompleks dankhas itu relatie sulit ditemukan pada jenis batik lain. Kombinasi warna yang kompleks dan seimbang menambah kesan estetik dan elegan.

\section{Potongan Ragam Hias yang Unik}

Ukuran dan bentuk bunga, tiap-tiap bintang laut pada motif tersebut tidak ada yang sama (berbeda). Hal tersebut dikarenakan batik tulis tersebut dibuat dengan memakai tangan (tradisional), yang berpotensi ktidaksamaan ukuran relatif tinggi. Berbeda dengan batik jenis lain, batik cap dan printing. Pada batik cap dan printing misalnya, ukuran, pola, motif, corak, bisa didesain dan setting dengan menggunakan alat cap bahkan teknologi mesin. Ukuran yang tidak sama tersebut (asimetri) tidak menjadi kekurangan atau kelemahan, tidak merusak sistem atau kesatuan motif dan desain. Asimetri batik tulis pada gambar 3 tersebut justru menambah daya tarik (penikmat atau khalayak) dan member kesan estetis.

\section{Simpulan}

Batik tulis motif "bintang laut" Pekalongan, Jawa Tengah memilki nilai keindahan ditinjau dari tiga unsur estetik pembentuk karya seni. Tiga unsur estetik tersebut, yaitu unity (keutuhan), dominance (penonjolan), dan balance (keseimbangan). Tiap-tiap unsur mempunyai indikator dan batasan estetika masing-masing. Unsur unity pada batik tulis tersebut terdapat kombinasi warna 
yang utuh yang membentuk motif. Kombinasi warna tersebut menjadi indah (dipandang). Keindahan lain juga ada pada segi dominance motif "bintang laut". Dominance atau penonjolan tersebut memberi kesan indah bagi para penikmat batik. Demikian halnya, balance. Kesimbangan yang dimaksud pada batik tersebut adalah tanpa simetri (asimetri) pada tiap lingkaran atau ukuran bintang laut. Gabungan ketiga unsur tersebut saling melengkapi, membentuk makna, dan memiliki keindahan batik tulis Pekalongan, Jawa Tengah.

Jika sebagian besar khalayak memilih dan suka batik pada umumnya karena keindahan dan keunikan motif. Maka, batik tulis motif "bintang laut" Pekalongan patut dipertimbangkan. Selama ini sebagian orang suka akan motif batik karena persepsi yang ditimbulkan oleh penglihatan mata sekilas. Padahal, jika dicermati secara mendalam dan dikaji dari estetika, terdapat keindahan motif dari kombinasi warna yang dihasilkan. Dari segi kajian esetetika (penelitian) terhadap batik tulis Pekalongan pun relatif sedikit dan terbatas. Beberapa penelitian yang dilakukan terkait batik Pekalongan lebih kepada sektor ekonomi (produksi, distribusi, dan konsumsi). Padahal jumlah motif batik (tulis, cap dan printing) di Pekalongan berkembang pesat. Masyarakat perlu dijelaskan keunggulan dan estetika batik kota Pekalongan secara ilmiah atau akademik. Oleh sebab itu, di sinilah perlunya penelitian lanjutan.

\section{Daftar Pustaka}

Djelantik, A.A.M. 2004. Estetika. Yogyakarta: Masyarakat Seni Pertunjukan Indonesia.

Latif, Rr. Vita Nur, dkk. 2016. "Profil Potensi Penyakit Akibat Kerja Tahapan Pembatikan”. Unnes Journal Public Health. Universitas Negeri Semarang.

Pramitasari, Afrinar. 2014. "Register Pelaku Industri Batik di Kota Pekalongan: Kajian Sosiolinguistis". Seloka: Jurnal Pendidikan Bahasa dan Sastra Indonesia. Universitas Negeri Semarang.

Rizza, Rafikhul. 2013. "Hubungan antara Kondisi Fisik Sumur Gali Dengan Kadar Nitrit Air Sumur Gali di Sekitar Sungai Tempat Pembuangan Limbah Cair Batik". Unnes Journal Public Health. Universitas Negeri Semarang. 
Salma, Irfa'ina Rohana dan Edi Eskak. 2012. "Kajian Estetika Desain Batik Khas Sleman 'Semarak Salak"'. Jurnal Dinamika Kerajinan dan Batik. Vol. 32, No. 2, Desember 2012. Jogjakarta.

Sundoko, Djoko. 2010. "Pemberdayaan Indutri Batik Skala Kecil di Jawa Tengah”. Disertasi S3 Fakultas Ekonomi dan Bisnis Universitas Diponegoro. 